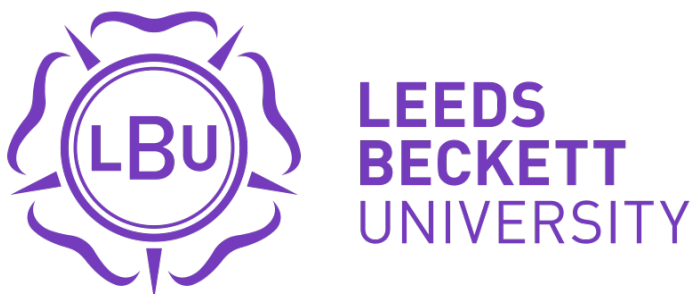

Citation:

Sun, WX (2015) Modes of Thinking in Corporate Governance: In Search of Root Causes of Governance Malfunctioning. Academy of Management Annual Meeting Proceedings. ISSN 0065-0668 DOI: https://doi.org/10.5465/AMBPP.2015.14211abstract

Link to Leeds Beckett Repository record:

https://eprints.leedsbeckett.ac.uk/id/eprint/4464/

Document Version:

Article (Accepted Version)

Creative Commons: Attribution-Noncommercial-No Derivative Works 4.0

The aim of the Leeds Beckett Repository is to provide open access to our research, as required by funder policies and permitted by publishers and copyright law.

The Leeds Beckett repository holds a wide range of publications, each of which has been checked for copyright and the relevant embargo period has been applied by the Research Services team.

We operate on a standard take-down policy. If you are the author or publisher of an output and you would like it removed from the repository, please contact us and we will investigate on a case-by-case basis.

Each thesis in the repository has been cleared where necessary by the author for third party copyright. If you would like a thesis to be removed from the repository or believe there is an issue with copyright, please contact us on openaccess@leedsbeckett.ac.uk and we will investigate on a case-by-case basis. 
MODES OF THINKING IN CORPORATE GOVERNANCE:

IN SEARCH OF ROOT CAUSES OF CORPORATE GOVERNANCE MALFUNCTIONING

\author{
William Sun \\ Leeds Business School \\ Leeds Beckett University, UK
}

Published in Academy of Management Proceedings 2015 


\title{
Modes of Thinking in Corporate Governance: \\ In Search of Root Causes of Corporate Governance Malfunctioning
}

\begin{abstract}
This paper argues that the current two prevailing modes of thinking in corporate governance, the inward-looking and outward-looking modes of thinking, severely limit and constrain our understandings of corporate governance systems and problems and are thus unable to properly diagnose and rectify corporate governance defects and malfunctions in practice. The paper presents a new mode of thinking, i.e., the critically reflexive mode of thinking, to overcome the limitations of the current modes of thinking, such as the assumed hard boundary between the internal and external governance systems, a simplistic "either or" approach to look into core corporate governance problems. The new mode of thinking suggests that the core corporate governance issues are not purely from inside the corporation, nor solely from outside the corporation. Rather, they actually reside at the intersection of internal and external governance spheres interplayed by corporate powers and political, market and other key stakeholder players. Illustrated by three key exemplary theses, the critically reflexive mode of thinking shows fundamental different understandings among the three modes of thinking. This mode of thinking points to a new direction in corporate governance research and a clearer agenda for effective corporate governance reforms.
\end{abstract}

\section{Keywords:}

Corporate governance, inward-looking mode of thinking, outward-looking mode of thinking, critically reflexive mode of thinking 


\section{Modes of Thinking in Corporate Governance: \\ In Search of Root Causes of Corporate Governance Malfunctioning}

\section{INTRODUCTION}

A commonplace observation is that corporate governance has largely failed in practice (e.g., Sun et al., 2011). This has been proved by a series of fraudulent scandals, corporate failures and irresponsible behaviours over a few of decades, particularly the scandals of Enron, WorldCom, Tyco and others around 2002, and corporate failures during the 2008 financial crisis. Corporate governance not just failed to prevent the 2008 financial crisis, but actually contributed to the crisis (e.g., Clarke, T., 2011; OECD, 2009; Tomasic, 2011). Since the financial crisis, despite a wave of new regulations and corporate governance codes in the United States and the United Kingdom, among other countries, corporate governance problems in the financial industry, as the then Governor of the Bank of England Mervyn King pointed out, remain the same (The Telegraph, 05 March 2011). These include the remorseless pursuit of short-term profit, excessive bonuses (even coming from taxpayers' money), banks' routine exploitation of their millions of customers and living in a "too-big-to-fail" world.

King warned that, without reforming the banks to tackle the fundamental governance issues, another financial crisis will be inevitable. Furthermore, corporate scandals like corruptions, money laundering, oil leaks, phone hacking, horse meat, and inadequate risk management have continued to occur. Corporate misbehaviours and wrongdoings have not just appeared in a few of companies; rather, they were often seen industry-wide, nationwide or even worldwide.

Corporate governance research has started as early as the modern corporate system was established in the mid- $19^{\text {th }}$ century. Since the late $20^{\text {th }}$ century, corporate governance 
theories in law, economics, management, politics and sociology have offered competing diagnoses of and remedies for corporate governance ailments (Clarke, T., 2004; Keasey et al, 1997). In the last two decades, for example, agency theory and stakeholder theory have gained popularity in corporate governance. Yet, the solutions they offered failed to resolve the problems they identified. The incentive schemes advocated by agency theory did not solve the agency problem, but created more governance problems (Wheatley, 2012). On the other side, stakeholder theory, as well as the concept of corporate social responsibility, did not change much the Anglo-American business landscape, and the sentiment of "business as usual" has always prevailed (Fleming and Jones, 2012). Stakeholder involvement in corporate governance has not been seriously treated in the Anglo-American corporate governance systems. Instead, the shareholder model has gained a great triumph since the 1980s with a significant worldwide influence (e.g., Coffee, 1999; Hansmann and Kraakman, 2001, 2012). Ironically, however, the recent financial crisis indicated that the shareholder model did not do well in practice and has appeared more negative than positive (e.g., Stout, 2012).

Why has corporate governance failed in both theory and practice? This paper suggests that current corporate governance theories and competing perspectives, as well as thoughts for guiding governance reforms, are based on two different modes of thinking to search for the root causes of corporate governance problems and find relevant solutions. One is to look inward to the internal corporate governance systems with a focus on refining internal governance structures and mechanisms, such as the composition and functioning of boards and incentive schemes. On the contrary, the alternative mode of thinking is to look outward to the external institutional environments to find some determined causal factors. This paper critiques the two modes of thinking in corporate governance on the ground that although they may have some merits both modes of thinking are but a traditional convenient way of thinking: either internal or external, - a polarised and simplified theory construction. Both are 
severely limited in understanding the more complicated institutional arrangements for corporate governance and both have failed to reveal how corporate governance is actually constructed in reality.

The paper argues instead that corporate governance reality is not purely constructed internally, nor solely externally, but "inter-externally". It means that it is the interconnection and interplay of internal and external governance forces and factors that plays a key role in shaping corporate governance: such as structures, mechanisms, values and cultures, and institutional arrangements. Accordingly, the root causes of corporate governance malfunctions need to be found at the intersection of internal and external corporate governance spheres. Here, "internal" and "external" are only used as convenient terms. In reality, the internal and external boundary is often blurred and fully dynamic. A critically reflexive mode of thinking is needed to recover the real face of corporate governance as a continuing political and social construct in context, rather than a naturally and universally generated or pre-given system or framework. Such a mode of thinking echoes somewhat Fiss' (2008) call for a criticallyreflective thinking in corporate governance that would bring back all of the corporate constituents into the focus of corporate governance research and see how governance is constructed at the intersection of various influence spheres and how corporate actors actively manage such constituent groups.

In the following sections, both inward-looking and outward-looking modes of thinking in corporate governance are identified and their limitations examined. Then, the alternative critically-reflexive mode of thinking in corporate governance is presented and its underlying theoretical foundations are provided. Key exemplary theses in the new and conventional modes of thinking are discussed and compared to illustrate the different understandings of corporate governance matters. A further discussion is given to the implications of the new mode of thinking for identifying the root causes of corporate governance defects and for a 
future corporate governance reform agenda. The paper concludes with remarks on its contributions and further research directions.

\section{THE INWARD MODE OF THINKING IN CORPORATE GOVERNANCE}

The modern corporate governance system was formally established by corporate law and other related laws to govern key relationships among shareholders, directors and executive managers of the corporation. In corporate law, shareholders are treated as members of a corporation. Thus, shareholders can be regarded as "internal" players in corporate governance rather than "outsiders". Such a normative legal framework is often taken for granted in mainstream governance thinking, as if corporate governance were only a matter of governance within the corporation or at the corporate level, concerning, for example, how the board is functioning in practice, how the relationships among the shareholders, directors and management can be strengthened or adjusted, and how the interests of managers and shareholders can be aligned.

Over time, the internal governance framework prescribed by laws eventually becomes a constrained mode of thinking. A search of the internet and academic texts can find that the most common discussions about corporate governance are all related to such internal governance issues. The inward-looking mode of thinking is especially embedded in the dominant corporate governance theory - agency theory (e.g., Fama, 1980; Jensen and Meckling, 1976), in which the only identified corporate governance problem is a universal agency problem. The key solution to it is to align the interest of managers with the interest of shareholders by strengthening the incentive system and introducing voluntary codes. External market mechanisms, like the market for corporate control, may be used to discipline managerial behaviour and thus enhance the internal governance system. The challenging 
stakeholder theory (e.g., Blair, 1995; Freeman, 1984) does not go far away from the inwardlooking mode of thinking, as it believes that the frequent occurrence of corporate governance problems in the Anglo-American environment is largely due to the absence of stakeholder involvement in corporate governance. Its solution thus requests a revision of the internal structure of corporate governance, such as involving stakeholders in corporate decisionmaking through stakeholder dialogue and consultation.

Corporate governance reforms over the last two decades have reinforced such an inward mode of thinking. For instance, a series of UK corporate governance reports and codes (Cadbury, 1992; Financial Reporting Council, 2010; Greenbury, 1995; Hampel, 1998; Higgs, 2003; Turnbull, 1999; Walker, 2009) defined corporate governance only in terms of the role and functioning of the board and the rights of shareholders, which is copied in the new Corporate Governance Code of 2010:

Corporate governance is therefore about what the board of a company does and how it sets the values of the company, and is to be distinguished from the day to day operational management of the company by full-time executives. (The UK Corporate Governance Code, 2010: 1).

This mode of thinking has been shared by the Organization for Economic Cooperation and Development (OECD) Principles of Corporate Governance (1999, 2004), as well as Corporate Governance Rating Systems, such as the Corporate Governance Quotient (CGO) and its recent replacement, Governance Risk Indicators (GRId), the S\&P Corporate Governance Score, the GMI rating system, and the Corporate Library's Board Analyst (Barrett et al., 2004; Daines et al., 2010). All of them have drawn people's attention to 
internal governance affairs only, like board accountability, management responsibility and compensation, disclosure and transparency, and shareholders' rights and equal treatment.

While looking inward to search corporate governance issues at the corporate level, such a mode of thinking artificially builds a hard corporate boundary and isolates it from the sounding environments, and ignores the interconnection of the corporate internal governance system with the larger political, economic and socio-cultural systems in which it is located. Moreover, the inward-looking mode of thinking often treats corporate governance as naturally and universally occurred or pre-given and neglects corporate governance systems as institutionally designed and arranged on purpose and as a result of political and social constructions.

\section{THE OUTWARD MODE OF THINKING IN CORPORATE GOVERNANCE}

In recent years, corporate governance thinking has been advanced by several nonconventional approaches and alternative perspectives, notably, the political model, the legal model, and the cultural model.

The political model has gained significant influence in corporate governance studies (e.g., Cioffi and Höpner, 2006; Grundfest, 1990; Pound 1993; Roe, 1994, 2000, 2003). This model argues that macro-level political forces and factors largely determine a structural framework of corporate governance. Corporate governance arrangements do not rely on a simple economic rationality but on broader political contexts. As Roe posits it:

Politics can affect a firm in many ways: it can determine who owns it, how big it can grow, what it can produce profitably, how it raises capital, who has the capital to invest, how 
managers or employees see themselves and one another, and how authority is distributed inside the firm. (Roe, 2003: 1)

Roe proposes a strong deterministic version of the political model, as he believes that the political determents tugging on the firm are "as strongly as the moon determines the tides.” (Roe, 2004: vi)

The legal model emphasises the central role of a country's legal system in shaping corporate governance. Many academics contend that the law is more deterministic in protecting minority shareholders and in influencing corporate finance and ownership structures (e.g., Beck et al., 2003; Cheffins, 2002; Choi, 2002; Coffee, 2001; Mahoney, 2001). The thesis was supported by large empirical research, particularly from the seminal work of La Porta, Lopez-de-Silanes, Shleifer, and Vishny (LLSV) (1997, 1998, 2000, 2002).

The cultural model claims that national cultures play a key role in both the origin and the future development of corporate governance systems (e.g., Licht, 2001, 2004; Licht et al., 2005; Tricker, 1990). It maintains that societal values, traditions, beliefs and assumptions may be more persistent than other factors in inducing path dependence and thus affect the development of corporate governance systems. Culture is viewed as the root cause of all of the difference (Landes, 2000).

The alternative perspectives proposed by scholars in economics, law, politics and sociology commonly look outwards to the institutional environments and infrastructures of corporations and try to figure out how corporate governance is rooted in and determined by political, legal and socio-cultural institutions. This is generally in line with a macro-level institutional approach or a new institutional approach to corporate governance called upon recently in sociology (Davis, 2005; Fiss, 2008). While this is a great leap forward in corporate governance research (as it breaks with the inward-looking mode of thinking), however, there 
are still actual and potential limits of such institutional approaches, such as dualism, determinism and the homeostatic nature of study.

Dualism views corporations and their environments as two relatively independent systems separated by an artificially inserted systemic boundary. Therefore, corporations must fit and adapt to their environments to survive. This view, however, downplays the interconnection and inseparability of the corporate system and its environment, as discussed later in the paper.

In association with dualism, determinism assumes that external and pre-existing environmental forces and factors can causally determine the formation and functioning of internal corporate governance. This is often seen in the recent argument that a single environmental element, such as a political or legal system, determines the system of corporate governance. But there are always counterarguments against any single determining variable. For example, Roe (2002) rejects legal determinism, while Coffee (2001) opposes political determinism. Furthermore, determinism refers to one-way thinking and a top-down approach, but the reality shows two-way interactions and mutual influences between the corporation and its surroundings. It is well recognised that major multinational corporations are economically more powerful than a single government (e.g., Korten, 2001). Thus, the sequence of which determines which is often a question. Environmental determinism looks single-minded.

The institutional approaches to corporate governance tend to be homeostatic in nature, as they emphasise structures, consistence and stability, whilst downplaying processes, diversity and dynamics of institutional developments. This problem has already been recognised by institutional theorists. For instance, Scott (2007) suggests that early institutional theory in sociology overstated the monolithic structure of institutional environments exerting influence in a unilateral manner on compliant organisations. Peters (2000) identifies three common features of various institutional approaches in political 
economy: (1) structures do matter, (2) structures persist while individuals come and go, and (3) structures create great regularity of human behaviour, which is predictable. Peters points out that the most important theoretical problem of institutional theory is the generally static nature of institutional explanations.

\section{A CRITICALLY-REFLEXIVE MODE OF THINKING IN CORPORATE GOVERNANCE}

If the inward mode of thinking cannot see the woods for the trees, the current institutional approaches tend to look over the woods without seeing the trees (or neglect how the woods are configured by the trees). The common problem in both inward and outward modes of thinking is the artificial separation of the internal and external governance systems with a clear-cut boundary. Corporate governance is viewed as either an independent system or an internal system entirely depending on the external environments to determine its fortune. While research interests in governance bundles tend to see the substitutability and complementarity of internal and external governance mechanisms (e.g., Rediker and Seth, 1995; Ward et al., 2009), the theory of governance bundles comes from an agency perspective and does not break up the internal-external boundary of governance systems.

The proposed critically-reflexive mode of thinking aims to overcome such limitations in current corporate governance research. First, it dissolves the corporate hard boundary imposed by the inward and outward modes of thinking and sees corporate governance as a system interconnected between the corporation and its political, social, cultural and economic environments. Fundamental problems of corporate governance often emerge from the interface of "internal" and "external" governance systems and processes where various corporate constituents and other players interact and interplay, rather than purely from inside 
or outside the corporation. Second, corporate governance is not a universally and naturally given system, but a political and social construct in a societal context which emerges at the intersection of various influence spheres from all of corporate constituents and managing actors (Fiss, 2008). Third, this new mode of thinking has a sense of not just looking inward, outward and across, but also backward and forward to see how corporate governance has contextually and conditionally emerged and changed over time towards uncertain future.

In the critically reflexive mode of thinking, corporate governance is defined as continuous processes of ordering and controlling actions and activities generated in corporate inter-relational webs through collectively constructed governing rules and instruments. Corporate governance aims at channelling corporate activities towards certain ends, and in so doing it is continuously shaped and reshaped by the dynamic interrelationships of all governing actors and players in and around the corporation. Three key characteristics of the governing processes underpin the critically reflexive mode of thinking, namely, wholeness, interconnectedness and emergence.

Wholeness. Corporate governance is explicitly and implicitly intricate in the entire political, economic and socio-cultural system in a society where the macroprocesses of governance organise the microprocesses into a systemic whole, and the two level governing processes are interlinked and coordinated rather than separated and isolated. Governance system at the corporate level is but a subsystem of the whole political, economic and sociocultural system in a society, or a part of the "metagovernance" system (i.e., governance of governance, a term used by Jessop (2002) and Kooiman (2003)). Understanding the reality of corporate governance, its issues, problems and solutions needs a holistic and contextual approach. This view is strongly supported by Meisel's (2004) study on corporate governance culture in France. He points out that "one cannot understand a country's institutions of corporate governance outside their interaction with their socio-political environment and, 
especially, with the country's institutions of political governance" (Meisel, 2004: 69). It is short-sighted to see corporate governance institutions isolated from the societal governance culture in which they are embedded (Meisel, 2004: 93).

Interconnectedness. A relational approach is often highlighted in the conventional economic and legal models of corporate governance. For instance, the corporation is commonly regarded as a "nexus of contracts" (e.g., Easterbrook and Fischel, 1991; Fama and Jensen, 1983; Jensen and Meckling, 1976), involving relational exchanges between rational principals and agents and other participants in the organisation. Yet, such a relationship concept is only a simple linkage and connection between separate entities and parts. In the critically reflexive mode of thinking, the concept of "interrelationship" is derived from process philosophy, which views the "internal" and "external" governance systems not as separated entities, but as interconnected processes, both of which are interdependent or functionally conjoined elements/parts in a systemic whole (see Sun, 2009). In such an interrelationship, each element intermingles and interpenetrates with others throughout the whole of space or a system, each embodies aspects of all of the others, and each contains the information of the whole (Bohm, 1980; G. W. Leibniz, in Rescher, 1996: 37). In this respect, the corporation is not simply a collection of contracts between different parties, but a locus of interrelationships between all of the participants and actors, where their interests are intertwined and complicated, and their interconnections and mutual influences are beyond purely contracts or market exchanges.

Emergence. The emerging nature of corporate governance highlights the changing, evolving, dynamic and complex nature of corporate governance reality that is rooted in the living experiences and interactions and in instantly renewing interrelations of corporate governing participants and actors. While continuously developing over time, the governing interrelationships have a trace of dynamically stabilised patterns manifested in a certain 
format or shape, such as in specific forms and structures of corporate governance. The changing and emerging interrelationships can never be predefined by abstract assumptions and ideal models, nor truly caught by post-event rules and regulations, although socially constructed ideological and regulatory frameworks may reweave the values and beliefs of corporate governing participants and actors through interactions.

\section{ILLUSTRATION: EXEMPLARY THESES IN THREE MODES OF THINKING}

In this section, the critically reflexive mode of thinking is applied to corporate governance practices to generate a few exemplary theses at the three levels of corporate governance: regulatory governance, market governance and stakeholder governance, a framework used by Sun et al. (2011). The understandings of corporate governance issues in the critically reflexive mode of thinking are compared with the understandings in other two modes of thinking in order to see the fundamental differences among them. The exemplary theses are for illustration only and do not exhaust all the potential theses to be generated there.

In the inward-looking mode of thinking, the internal governance system is separate from the external environment in the first place and then mechanically linked to it. Thus, external governance on the corporation is often regarded as an extra burden, or a restraint, something imposed on or added to internal governance from outside. Scholars and researchers who concentrate on refining the internal governance framework often argue against strong regulation, market restriction and stakeholder participation in corporate governance, and are in turn in favour of self-regulation, free market competition and instrumental stakeholder management. On the other side, in the outward-looking mode of thinking, regulatory, market and stakeholder forces seem to be much more deterministic in shaping the internal governance landscape. People thinking in this way often assume or assert firms' compliance (willing or 
unwilling) with regulations, the overwhelming power of market forces in disciplining corporate behaviour and performance, and the importance of stakeholder pressure and influence on corporate decision making.

In the critically-reflexive mode of thinking, however, the key governance issues identified are quite different from those in the inward and outward modes of thinking. Three exemplary theses in regulatory governance, market governance and stakeholder governance are illustrated below.

Thesis One: The Business-Political Nexus. In terms of regulatory governance, neither self-regulation (from the inward mode of thinking) nor compliance (from the outward mode of thinking) can be seen as somewhat ideal, pre-given and/or taken-for-granted governance mechanisms, but simply as particular types of institutional arrangements in a society at a given time. The key question is how the institutional arrangements are actually made in reality. The assertion is that neither corporations nor external regulators alone can simply make such arrangements. Self-regulation or state regulation is often a result of the interplay between corporations and regulatory forces (plus pressure groups sometimes). This is frequently evidenced in corporate lobbying for or against certain regulations (which is termed "regulatory capture" in economics, e.g., Stigler, 1971) and lobbying for widely advocated deregulation and self-regulation. It is also evidenced in firms' close link to political parties and politicians. For instance, following Olson (1982, 1996), Edwards (2009) demonstrates that the City of London (the financial centre or sector) has long been a powerful rent-seeking interest group, a "distributional coalition", with its overriding objective to redistribute income and wealth to itself and to maximise its profits in the short term. One of the important means for this purpose is self-regulation, that is, free of government intervention in general and restrictive practices legislation in particular. The City has very successfully secured the selfregulation policy since the $19^{\text {th }}$ century through its close relationship with the Bank of 
England and H. M. Treasury, known as the "City-Bank-Treasury nexus or axis" or the C-B-T nexus. The nexus is an interdependent political-business league, where each party's interests and objectives depend on the other two parties to fulfil. With the C-B-T nexus, the City has long been able to influence state decision-making at the highest levels.

Cioffi and Höpner (2006) also note that the formation of the post-war political economy and corporate governance frameworks was largely the political expedience, personal economic interest and ideological conviction of the centre-right parties in the West. The favour for managerialism was "the legacy of class-based party formation [that] embodied long-standing alliances between centre-right parties and corporate managers" and the close personal and professional ties between them (Cioffi and Höpner, 2006: 486). Ideologically, the centre-right has had a historical affinity with employers' interests against working class interests.

Thesis Two: Market Inefficiency and Manipulation. In terms of market governance, many people (though not all) in the inward and outward modes of thinking tend to have a genuine faith in market efficiency and/or market determinism, and claim that disclosure, transparency and market discipline are effective corporate governance mechanisms. However, the efficient market hypothesis has to rely on an even flow of information through to the market, but this is not the case in reality. Schwarcz (2011), for example, reveals that in the United States although most of the risks were disclosed in the financial market before the financial crisis as required by the federal regulations, the disclosure was ineffective due to information asymmetry and information failure. For Schwarcz, information asymmetry and failure is the direct cause of market inefficiency. Joseph E. Stiglitz, a Nobel laureate in economics, holds a similar view that "information imperfections are central in finance" and "when information is imperfect, markets do not often work well" (Stiglitz, 2009: 9). In a recent government-backed review of the UK equity markets and long-term decision making, 
Kay (2012) criticises the efficient market hypothesis and argues that it provides a poor basis for either regulation or investment. It also drives short-term decisions by investors at the expense of corporate long-term growth and the whole economy.

In the critically reflexive mode of thinking, markets are not merely economic exchange places based on purely calculative and deterministic economic conditions, as assumed in classical and neo-classical economics. Rather, markets are social constructs, the results of socially interactive and interrelated processes, which are not simply and straightforwardly rational and efficient (Fligstein, 1990; Hampden-Turner and Trompenaars, 1994; Rescher, 1988; Roy, 1997). Rather than disciplining corporate management, the marketplace is an extension of corporate management's power and interests. This is usually done through market manipulation by corporations and their close alliances in the markets, such as securities analysts, auditors, accounting firms, lawyers and ratings agencies, with deliberate attempts to create artificial, false or misleading information or appearances of trades in the markets for securities, commodities or currencies to control and gain from the markets (Sears, 1997). The Enron and Arthur Andersen scandal in 2001 proved this case. The 2008 financial crisis was also caused by market manipulation, in which hedge funds within commercial banks and investment banks played a significant role (Stein, 2008; for a typical evidence of market manipulation during the financial crisis, see Misra et al. 2012). The recent scandal of the inter-banking rate fixing by Barclays and many other banks is another example of market manipulation in the financial crisis. Therefore, for Stein (2008), Wall Street has changed "from a financing entity to a market manipulation entity".

Thesis Three: Stakeholder Manipulation and Conflict of Interest. In the inward mode of thinking, stakeholder interests are ignored or treated purely as an instrument for corporate strategic management. There is little room for considering wider stakeholder interests in the shareholder model. By contrast, the outward mode of thinking believes that stakeholder forces 
are so powerful in determining/influencing corporate governance and performance that corporations seem to be subordinated to stakeholder pressures. However, evidence shows that this claim may not be true in reality (Letza et al., 2004). Large corporations are not passive, but active, in response to institutional/stakeholder pressures and expectations. Corporate active role has long been neglected by institutional theory (Oliver, 1991). As mentioned previously, corporations may build close ties with politicians and regulators to manipulate regulations and may form coalitions with key market players to manipulate markets. In short, corporations may collude with one or a few of stakeholder groups to pursue gains at the costs of all others.

The attempt to co-opt, influence or control institutional and stakeholder pressures and evaluations is termed the "manipulation strategy" by Oliver (1991), who identifies several strategies used by organisations in response to institutional processes. With the manipulation strategy, corporations may co-opt the source of the stakeholder pressure by, for example, persuading key stakeholder groups' representatives to join the corporation or its board of directors, or opportunistically use institutional links and ties to seek external supports. Corporations may influence institutionalised values and beliefs or definitions and criteria of acceptable practices and performances. Corporations may directly control stakeholder pressures by, for instance, controlling the budgetary processes used to assess the value of corporate social and economic contributions, or by striving to alter the way in which corporate achievements and transgressions are announced to the public (Oliver, 1991: 157-159).

In the stakeholder manipulation process, conflicts of interest are inevitable. A conflict of interests occurs when professional judgment or actions regarding a primary interest of the profession are unduly influenced by a secondary interest of the same profession (Thompson, 1993). When professions, such as auditors and rating agencies, are paid by companies to evaluate the same companies' financial reports, asset values or performance, a conflict of 
interest occurs. If the professions also provide additional services, such as consultancy and advice, to the same companies, the conflict of interest could be severe. For instance, prior to the 2008 financial crisis, the rating agencies were involved in advising companies how to structure derivatives to get desired ratings. This presented serious conflicts of interest (Kirkpatrick, 2009). It is commonly believed that the sharp contrast between the very rosy ratings before the financial crisis and the dramatic downgrades at the beginning of the financial crisis contributed to the global financial meltdown (e.g., Clarke, T., 2011; FCIC, 2011).

A brief summary of the above-mentioned key theses in the three modes of thinking is shown in Table 1. The different understandings of corporate governance issues are seen strikingly.

Insert Table 1 about here

\section{IMPLICATIONS AND DISCUSSIONS}

The critically reflexive mode of thinking points to a deep understanding of corporate governance problems in practice, which is fundamentally different from the current mainstream or popular understandings. It believes that the core problems of corporate governance are not purely from within corporations, nor solely determined by external institutions, but emerged from the interplay of corporations and various institutional players, including political, legal, market and other key stakeholder players. Surely, an interplay of the influential forces may have either positive or negative impacts on corporate governance, depending on what intentions those players hold and how well the internal and external forces 
in play are checked and balanced and publically monitored in a democratic society. If the dependent conditions are weak, the negative impacts would surpass the positive impacts (if any).

The current dominant mode of thinking and resultant corporate governance reforms, while focused on the internal governance system, fail to address the issues at the intersection of the internal and external governance spheres and fail to recognise the practices of corporate governance have actually been "captured" by the interlink and interplay of internal and external governing forces. This is the root cause of the persistent corporate governance problems that have not been touched in corporate governance reforms over the last two decades. It is important that corporate governance reforms need to address the failures in regulatory, market and stakeholder governance, rather than internal governance alone. Reform priority should be given to such key issues as regulatory capture, market manipulation and stakeholders' conflict of interests.

As the world is fundamentally interconnected, businesses cannot be isolated from political systems. Instead, businesses are embedded locally in political, economic and social institutions; and vice versa, political and social relations are embedded in business and the economic system (Granovetter, 1985; Polanyi, 2001; for an updated literature review on the concept of embeddedness, see Heidenreich, 2012). However, if a business-political link generates negative consequences that are harmful to the economy and society as a whole, measures must be taken to protect the whole system and the general public. In recent years, there have been increasing studies on regulatory capture since Stigler (1971). A new collection of papers edited by Pagliari (2012) has addressed the regulatory capture issue more substantially, based on perspectives from academics, regulators and stakeholders. The book presents three broad policy approaches to mitigate the risk of regulatory capture. Firstly, it is needed to rebalance the participation of stakeholders and to strengthen the plurality of voices 
in the regulatory process. The regulatory participation process should be fair, transparent, accessible, and open. Secondly, regulatory agencies should be granted an independent status by statute, and then the regulatory processes should be insulated from the political horsetrading and short-term pressures of politicians. Thirdly, the regulatory processes should be opened to different external checks and balances to ensure that regulatory authorities are constantly supervised, held accountable, and challenged. While the above suggestions and measures sound rational and reasonable, some deeper issues remain little touched in the book. For example, who will regulate the regulators and how? Who, then, will regulate the regulators of regulators and how? If unfair and perverse business lobbying, political donations, and close-door business-political trades are permitted either explicitly or implicitly, regulatory capture is hardly resolvable. The core issue is more related to the existing complication of business-political interlink system, what Harvard Law School Professor Lawrence Lessig (2011) calls "a legal but corrupt system", a system that needs to be deeply reformed to be more open, just, transparent and democratic.

Free market looks ideal for corporate governance only if widespread market manipulation is effectively contained. Market manipulation was a major concern during the Great Depression. Major legislation and regulations was laid down in the 1930s and thereafter to prevent market manipulation and fraud. However, the deregulation movement that began in the 1980s changed the business regulatory landscape and provided opportunities for market abuse. The only way to prevent market abuse is to impose restricted rules with criminal penalties. Self-regulation did not work and will not work. Only financial penalties are not enough, as the imposed fines are usually far less than the benefits accrued from the market manipulation. The manipulators simply walked away with no time served. Remarking on the Barclay's Libor manipulation scandal, the UK Business secretary Vince Cable pointed out that the public “just can't understand why people are thrown in jail for petty theft and these 
guys just walk away having perpetrated what looks like conspiracy” (Muñoz and Colchester, 2012). In response to the Enron scandal, the unprecedented tough legislation of the SarbanesOxley Act of 2002 did increase criminal penalties for manipulation, destruction or alteration of financial records or other interference with investigations. But, the Act was designed only to ensure the accuracy and transparency of corporate financial information. It did nothing to prevent market abuse and manipulation outside corporate accounting and auditing. Still, there is a large regulatory vacuum in the markets that awaits the attention of legislators.

Proper regulations are also needed to prevent conflict of interests and corporatestakeholder collusions that may act against the public interest. Regulations should set clear guidance or procedures for organisations and professionals to remove, avoid, disclose, and recuse themselves from conflict of interests in every industry, sector and professional field. Corporate-stakeholder collusions of any type against the public interest should be prohibited. The key regulatory issue should relate to some ambiguous and controversial areas in which wrongdoings from conflict of interests are not kept in check or punished. If rating agencies, for example, give incorrect, inaccurate, biased or misleading ratings, whether intentionally or unintentionally, due to conflict of interests, what penalties should they receive? Although credit rating agencies clearly knew about Enron's problems for months, they kept its rating at investment grade until four days before its bankruptcy (Borrus, 2002). Yet, those rating agencies did not receive any punishment. After Enron, the Sarbanes-Oxley Act of 2002 requested only that the Securities and Exchange Commission (SEC) develop a review report on how credit ratings are used in the American regulatory scheme and the policy issues arising from that use. The Credit Rating Reform Act of 2006 and the SEC's implementation of the Act in 2007 simply relied on rating agencies themselves to establish policies and procedures to avoid conflict of interests, to disclose conflict of interests to the public, and to furnish the SEC with an additional report about the number of credit rating actions 
(Parmeggiani, 2012). Nothing serious was done until the 2008 financial crisis in which the credit rating agencies played an important role. In 2011, the SEC made a major proposal to remove credit ratings as one of the conditions for companies seeking to use short-form registration when registering securities for public sale (SEC, 2011). In early 2012, the European Parliament Economic and Monetary Affairs Committee proposed that credit ratings be removed from European Union laws for regulatory purposes (Ryan, 2012). Obviously, regulation has not done enough to control improper corporate-stakeholder collusions and conflicts of interests.

\section{CONCLUSION}

The current inward and outward modes of thinking severely limit and constrain our understandings of corporate governance systems and problems and are thus unable to properly diagnose and rectify corporate governance defects and malfunctions in practice. The decadelong corporate governance reforms informed by the dominant inward-looking mode of thinking failed to prevent a systemic failure of corporate governance in the 2008 financial crisis. Overcoming the limitations of the existing modes of thinking, the proposed critically reflexive mode of thinking enables us to break the boundary of internal corporate governance system and external institutional environments and avoid a simplistic "either or" approach to look into core corporate governance problems. It allows us to trace the core corporate governance issues that resides at the intersection of internal and external governance spheres with an interplay by corporate powers and political, market and other key stakeholder players. When three key exemplary theses are emerged and examined at the regulatory, market and stakeholder governance levels, this new mode of thinking immediately captures such deep problems of corporate governance as regulatory capture, market manipulation and stakeholder 
manipulation and conflict of interests, which are rarely discussed in contemporary corporate governance research. This mode of thinking points to a new direction in corporate governance research and a clearer agenda for effective corporate governance reforms.

While the exemplary theses generated are for illustration only, the paper is not possible to examine a full spectrum of theses that might emerge from the interlink and interplay of internal and external governance systems and forces. Therefore, in search of the root causes of corporate governance problems, this paper only concentrates on a selected few. Moreover, the possible positive sides of the interlink and interplay are not discussed in the paper. All those leave a sufficient space for a further comprehensive research on the interface of internal and external governance systems and processes and on the role corporations have played and will continue to play in a society. This requires a much broadened thinking and more integrated multidisciplinary research on corporate governance beyond the current constraints (Clarke, T., 2007; Letza et al., 2008; Monks and Minow, 2001; Sun et al., 2011).

\section{REFERENCES}

Barrett, A., Todd, P. \& Schlaudecker, C. 2004. Corporate governance ratings. CDF Corporate Governance Committee, Towers Perrin, USA.

Beck, T., Demirgüç-Kunt, A., \& Levine, R. 2003. Law and finance: why does legal origin matter? Journal of Comparative Economics, 31: 653-675.

Bohm D. 1980. Wholeness and the implicate order. London: Routledge and Kegan Paul.

Borrus, A. 2002. The credit-raters: how they work and how they might work better. BusinessWeek, 8 April.

Cadbury A. 1992. Report of the committee on the financial aspects of corporate governance. London: Gee and Co.

Cheffins, B. R. 2002. Corporate law and ownership structure: a Darwinian link? The University of New South Wales Law Journal, 25: 346-378. 
Choi, S. J. 2002. Law, finance, and path dependence: developing strong securities markets. Texas Law Review, 80: 1657, 1660-1695.

Cioffi, J. W. \& Höpner, M. 2006. The political paradox of finance capitalism: interests, preferences, and centre-left party politics in corporate governance reform. Politics $\&$ Society, 34: 463-502.

Clarke, T. 2004. Theories of corporate governance: the philosophical foundations of corporate governance. London: Routledge.

Clarke, T. 2007. International corporate governance: a comparative approach. London: Routledge.

Clarke, T. 2011. Corporate governance causes of the global financial crisis. In W., Sun, J. Stewart, \& D. Pollard, (Eds.), Corporate governance and the global financial crisis: international perspectives. Cambridge: Cambridge University Press.

Coffee, J. C. 1999. The future as history: the prospects for global convergence in corporate governance and its implications. Northwestern University Law Review, 93: 641-707.

Coffee, J. C. 2001. The rise of dispersed ownership: the roles of law and the state in the separation of ownership and control. The Yale Law Journal, 111: 1-82.

Daines, R. M., Gow, I. D., and Larcker, D. F. 2010. Rating the ratings: how good are commercial governance ratings? Journal of Financial Economics, 98: 439-461.

Davis, G. F. 2005. New directions in corporate governance. Annual Review of Sociology, 31: 143-162.

Easterbrook, F. H. and Fischel, D. 1991. The economic structure of corporate law. Cambridge, Mass.: Harvard University Press.

Edwards, I. F. 2009. The role of finance in Britain's economic decline. Unpublished PhD thesis, Leeds University, Leeds.

Fama, E. \& Jensen M. C. 1983. Separation of ownership and control. Journal of Law and Economics, 26: 301-326.

Fama, E. 1980. Agency problems and the theory of the firm. Journal of Political Economy, 88: 288-309.

FCIC (Financial Crisis Inquiry Commission) 2011. The financial crisis inquiry report. Washington, D. C.: U.S. Government Printing Office.

Financial Reporting Council, The 2010. The UK corporate governance code. London.

Fiss, P. C. 2008. Institutions and corporate governance. In R. Greenwood, C. Oliver, R. Suddaby, \& K. Sahlin (Eds.), The Sage handbook of organizational institutionalism. London: Sage. 
Fleming, P. \& Jones, M. T. 2012. The end of corporate social responsibility: crisis and critique. London: Sage.

Fligstein, N. 1990. The transformation of corporate control. Cambridge, MA: Harvard University Press.

Granovetter, M. 1985. Economic action and social structure: the problem of embeddedness. American Journal of Sociology, 91: 481-510.

Greenbury, C. 1995. Directors' remuneration: report of a study group. London: Gee.

Gundfest, J. 1990. Subordination of American capital. Journal of Financial Economics, 27: 89-114.

Hampden-Turner C. \& Trompenaars F. 1994. The seven cultures of capitalism. New York: Doubleday.

Hampel, C. 1998. Committee on Corporate Governance: Final Report. London: Gee.

Hansmann, H. \& Kraakman, R. 2001. The End of history for corporate law. Georgetown Law Journal, 89: 439-468.

Hansmann, H. \& Kraakman, R. 2012. Reflections on the end of history for corporate law. In A. A. Rasheed \& T. Yoshikawa (Eds), The Convergence of Corporate Governance: Promise and Prospects. Hampshire: Palgrave Macmillan.

Heidenreich, M. 2012. The social embeddedness of multinational companies: a literature review. Socio-Economic Review, 1-31.

Higgs, D. 2003. Review of the Role and Effectiveness of Non-Executive Directors. Department of Trade and Industry; London.

Jensen, M. C. \& Meckling, W. H. 1976. Theory of the firm: managerial behaviour, agency costs, and ownership structure. Journal of Financial Economics, 3: 305-360.

Jessop, B. 2002. Governance and metagovernance: on reflexivity, requisite variety and requisite irony. In H. Hang (Ed.), Governance, governmentality and democracy. Manchester: Manchester University Press.

Kay, J. 2012. The Kay review of UK equity markets and long-term decision making. http://www.bis.gov.uk/kayreview (accessed on 8 August 2012).

Keasey, K., Thompson, S., \& Wright, M. 1997. Introduction: the corporate governance problem-competing diagnoses and solutions. In K. Keasey, S. Thompson, \& M. Wright (Eds), Corporate governance: economic and financial issues. Oxford: Oxford University Press.

Kirkpatrick, G. 2009. The corporate governance lessons from the financial crisis. The OECD Steering Group on Corporate Governance, Paris. 
Kooiman, J. 2003. Governing as governance. London: Sage.

Korten, D. C. 2001. When corporations rule the world (2nd edition). San Francisco, CA: Berrett-Koehler Publishers.

La Porta, R., Lopez-de-Silanes, F., Shleifer, A., \& Vishny, R. 1997. Legal determinants of external finance. Journal of Finance, 52: 1131-1150.

La Porta, R., Lopez-de-Silanes, F., Shleifer, A., \& Vishny, R. 1998. Law and finance. Journal of Political Economy, 106: 1113-1155.

La Porta, R., Lopez-de-Silanes, F., Shleifer, A., \& Vishny, R. 2000. Investor protection and corporate governance. Journal of Financial Economics, 58: 3-27.

La Porta, R., Lopez-de-Silanes, F., Shleifer, A., \& Vishny, R. 2002. Investor protection and corporate valuation. Journal of Finance, 57: 1147-1170.

Landes, D. 2000. Culture makes almost all of the difference. In L. E. Harrison \& S. P. Huntington (Eds.), Culture matters: how values shape human progress. New York: Basic Books.

Lessign, L. 2011. Republic, lost: how money corrupts congress - and a plan to stop it. New York: Twelve.

Letza, S., Kirkbride, J., Sun, X., \& Smallman, C. 2008. Corporate governance theorising: limits, critics and alternatives. International Journal of Law and Management, 50: 17 32.

Letza, S., Sun, X., \& Kirkbride, J. 2004. Shareholding versus stakeholding: a critical review of corporate governance. Corporate Governance: An International Review, 12: 242-262.

Licht, A. N. 2001. The mother of all path dependencies: toward a cross-cultural theory of corporate governance systems. Delaware Journal of Corporate Law, 26: 147-205.

Licht, A. N. 2004. Legal plug-ins, cultural distance, cross-listing, and corporate governance reform. Berkeley International Law Journal, 22, 195-239.

Licht, A. N., Goldschmidt, C., \& Schwartz, S. H. 2005. Culture, law, and corporate governance. International Review of Law and Economics, 25: 229-255.

Mahoney, P. G. 2001. The common law and economic growth: Hayek might be right. Journal of Legal Studies, 30: 503-525.

Meisel, N. 2004. Governance culture and development: a different perspective on corporate governance. Paris: OECD Publishing.

Misra, V., Lagi, M., \& Bar-Yam, Y. 2012. Evidence of market manipulation in the financial crisis. New England Complex Systems Institute, Cambridge, MA. 
Monks, R. A. G \& Minow, N. 2001. Corporate governance ( $2^{\text {nd }}$ ed). Malden, M. A.: Blackwell.

Muñoz, S. S. \& Colchester, M. 2012. Barclays's Agius is stepping down. The Wall Street Journal, European edition, July 1.

OECD 1999. OECD principles of corporate governance. Paris: OECD Publications.

OECD 2004. OECD principles of corporate governance. Paris: OECD Publications.

OECD 2009. Corporate governance and the financial crisis: key findings and main messages. The OECD Steering Group on Corporate Governance, OECD, Paris.

Oliver, C. 1991. Strategic responses to institutional processes. Academy of Management Review, 16: 145-179.

Olson, M. 1982. The rise and decline of nations. New Haven, C. T.: Yale University Press.

Olson, M. 1996. The varieties of Eurosclerosis: the rise and decline of nations since 1982. In N. Crafts \& G. Toniolo (Eds.), Economic growth in Europe since 1945. Cambridge: Cambridge University Press.

Pagliari, S. (Ed.) 2012. Making good financial regulation: towards a policy response to regulatory capture. London: Grosvenor House Publishing.

Parmeggiani, F. 2012. The regulation of credit rating agency across USA and EU: different systems, same concerns. http://www.academia.edu/815900 (accessed on 20 September 2012).

Peters, G. 2000. Institutional theory: problems and prospects. Political Science Series 69, Institute for Advanced Studies (IHS), Vienna.

Polanyi, K. 2001. The great transformation: the political and economic origins of our time. Boston: Beacon Press.

Pound, J. 1993. The rise of the political model of corporate governance and corporate control. New York University Law Review, 68: 1003-1071.

Rediker, K. J. \& Seth, a. 1995. Boards of directors and substitution effects of alternative governance mechanisms. Strategic Management Journal, 16: 85-99.

Rescher, N. 1988. Rationality: a philosophical inquiry into the nature and the rationale of reason. New York: Oxford University Press.

Rescher, N. 1996. Process metaphysics. Albany, N.Y.: State University of New York Press.

Roe, M. J. 1994. Strong managers, weak owners: the political roots of American corporate finance. Princeton: Princeton University Press. 
Roe, M. J. 2000. Corporate reorganization and bankruptcy: legal and financial materials. New York: Foundation Press.

Roe, M. J. 2002. Corporate law's limits. Journal of Legal Studies, 31: 233-267.

Roe, M. J. 2003. Political determinants of corporate governance: political conflict, corporate impact. Oxford: Oxford University Press.

Roy, W. G. 1997. Socialising capital. Princeton: Princeton University Press.

Ryan, J. 2012. Do we need Credit Rating Agencies? Social Europe, 16 March.

Schwarcz, S. L. 2011. Information asymmetry and information failure: disclosure problems in complex financial markets. In Sun, W., Stewart, J., \& Pollard, D. (Eds.), Corporate governance and the global financial crisis: international perspectives. Cambridge: Cambridge University Press.

Scott, W. R. 2007. Institutional theory: contributing to a theoretical research programme. In Smith, K. G. \& Hitt, M. A. (Eds.), Great minds in management: the process of theory development. Oxford: Oxford University Press.

Sears, G. 1997. Market manipulation. Bank of England Publications Issue 203, London.

SEC 2011. SEC proposes first in series of rule amendments to remove references to credit ratings. SEC press release, 09 February.

Stein, B. 2008. Making sense of a scared new world. The New York Times, 23 March.

Stigler, G. 1971. The theory of economic regulation. Bell Journal of Economics and Management Science, 3: 3-18.

Stiglitz, J. E. 2009. Harsh lessons we may need to learn again. China Daily, 31 December.

Stout, L. 2012. The shareholder value myth: how putting shareholders first harms investors, corporations, and the public. San Francisco, C. A.: Berrett-Koehler.

Sun, W. 2009. How to govern corporations so they serve the public good: a theory of corporate governance emergence. New York: Edwin Mellen Press.

Sun, W., Stewart, J., \& Pollard, D. (Eds.) 2011. Corporate governance and the global financial crisis: international perspectives. Cambridge: Cambridge University Press.

Thompson, D. 1993. Understanding financial conflicts of interest. New England Journal of Medicine, 329: 573-576.

Tomasic, R. 2011. The failure of corporate governance and the limits of law: British banks and the global financial crisis. In W. Sun, J. Stewart, \& D. Pollard (Eds.), Corporate governance and the global financial crisis: international perspectives. Cambridge: Cambridge University Press. 
Tricker, R. I. 1990. Corporate governance: a ripple on the cultural reflection. In Clegg, S. \& Redding, S. G. (Eds.), Capitalism in contrasting cultures. Berlin: DeGruyter.

Turnbull, C. 1999. Internal control: guidance for directors on the combined code. The Institute of Chartered Accountants in England \& Wales, London.

Walker, D. 2009. A review of corporate governance in UK banks and other financial industry entities. The Walker review secretariat, London.

Ward, A. J., Brown, J. A., \& Rodriguez, D. 2009. Governance bundles, firm performance, and the substitutability and complementarity of governance mechanisms. Corporate Governance: An International Review, 17(5): 646-660.

Wheatley, M. 2012. The incentivisation of sales staff - are consumers getting a fair deal? UK Financial Services Authority (FSA), 5 September. 
TABLE 1

Exemplary Theses in Different Modes of Thinking

\begin{tabular}{|c|c|c|c|}
\hline & $\begin{array}{l}\text { The Inward-Looking } \\
\text { Mode of Thinking }\end{array}$ & $\begin{array}{l}\text { The Outward- } \\
\text { Looking Mode of } \\
\text { Thinking }\end{array}$ & $\begin{array}{l}\text { The Critically-Reflexive } \\
\text { Mode of Thinking }\end{array}$ \\
\hline $\begin{array}{l}\text { Regulatory } \\
\text { Governance }\end{array}$ & Self-regulation & Compliance & $\begin{array}{l}\text { Business-political nexus } \\
\text { Regulatory capture }\end{array}$ \\
\hline $\begin{array}{l}\text { Market } \\
\text { Governance }\end{array}$ & Free market exchange & Market discipline & $\begin{array}{l}\text { Market manipulation } \\
\text { Market inefficiency/failure }\end{array}$ \\
\hline $\begin{array}{l}\text { Stakeholder } \\
\text { Governance }\end{array}$ & $\begin{array}{l}\text { Stakeholder } \\
\text { management }\end{array}$ & $\begin{array}{l}\text { Stakeholder } \\
\text { power/influence }\end{array}$ & $\begin{array}{l}\text { Stakeholder manipulation/co- } \\
\text { option } \\
\text { Stakeholders' conflicts of } \\
\text { interest }\end{array}$ \\
\hline
\end{tabular}

